\title{
Nickel and Zinc Removal from Acid Mine Drainage: Roles of Sludge Surface Area and Neutralising Agents
}

\author{
William E. Olds, ${ }^{1,2}$ Daniel C. W. Tsang, ${ }^{2,3}$ Paul A. Weber, ${ }^{1}$ and Chris G. Weisener ${ }^{4}$ \\ ${ }^{1}$ Solid Energy New Zealand Ltd, Private Bag 1303, Christchurch 8024, New Zealand \\ ${ }^{2}$ Department of Civil and Natural Resources Engineering, University of Canterbury, Christchurch 8140, New Zealand \\ ${ }^{3}$ Department of Civil and Environmental Engineering, Hong Kong Polytechnic University, Hung Hom, Kowloon, Hong Kong \\ ${ }^{4}$ Great Lakes Institute for Environmental Science, University of Windsor, ON, Canada N9B 3P4
}

Correspondence should be addressed to Daniel C. W. Tsang; dan.tsang@polyu.edu.hk

Received 28 June 2013; Accepted 26 September 2013

Academic Editor: Yong Sik Ok

Copyright (C) 2013 William E. Olds et al. This is an open access article distributed under the Creative Commons Attribution License, which permits unrestricted use, distribution, and reproduction in any medium, provided the original work is properly cited.

\begin{abstract}
During acid mine drainage (AMD) treatment by alkaline reagent neutralisation, Ni and $\mathrm{Zn}$ are partially removed via sorption to Fe and $\mathrm{Al}$ hydroxide precipitates. This research evaluated the effect of surface area of precipitates, formed by neutralisation of AMD using three alkalinity reagents $\left(\mathrm{NaOH}, \mathrm{Ca}(\mathrm{OH})_{2}\right.$, and $\left.\mathrm{CaCO}_{3}\right)$, on the sorption of $\mathrm{Ni}$ and $\mathrm{Zn}$. The $\mathrm{BET}$ surface area of the precipitates formed by neutralisation of AMD with $\mathrm{NaOH}\left(173.7 \mathrm{~m}^{2} \mathrm{~g}^{-1}\right)$ and $\mathrm{Ca}(\mathrm{OH})_{2}\left(168.2 \mathrm{~m}^{2} \mathrm{~g}^{-1}\right)$ was an order of magnitude greater than that produced by $\mathrm{CaCO}_{3}$ neutralisation $\left(16.7 \mathrm{~m}^{2} \mathrm{~g}^{-1}\right)$. At $\mathrm{pH}$ 6.5, the residual Ni concentration was 0.32 and $0.41 \mathrm{mg} \mathrm{L}^{-1}$ for $\mathrm{NaOH}$ and $\mathrm{Ca}(\mathrm{OH})_{2}$ neutralised $\mathrm{AMD}$, respectively, resulting in up to $60 \%$ lower $\mathrm{Ni}$ concentrations than achieved by $\mathrm{CaCO}_{3}$ neutralisation which had no effect on $\mathrm{Ni}$ removal. The residual $\mathrm{Zn}$ concentration was even more dependent on precipitate surface area for $\mathrm{NaOH}$ and $\mathrm{Ca}(\mathrm{OH})_{2}$ neutralised $\mathrm{AMD}\left(0.33\right.$ and $\left.1.02 \mathrm{mg} \mathrm{L}^{-1}\right)$, which was up to $85 \%$ lower than the $\mathrm{CaCO}_{3}$ neutralised $\mathrm{AMD}\left(2.20 \mathrm{mg} \mathrm{L}{ }^{-1}\right)$. These results suggest that the surface area of precipitated flocs and the selection of neutralising reagent critically affect the sorption of $\mathrm{Ni}$ and $\mathrm{Zn}$ during AMD neutralisation.
\end{abstract}

\section{Introduction}

Acid mine drainage (AMD) is one of the major environmental impacts of coal mines that disturb pyritic overburden on the West Coast of the South Island of New Zealand [1]. The formation of acidity associated with AMD is illustrated by

$$
\mathrm{FeS}_{2}+\frac{7}{2} \mathrm{H}_{2} \mathrm{O}+\frac{15}{4} \mathrm{O}_{2} \Longrightarrow \mathrm{Fe}(\mathrm{OH})_{3}+2 \mathrm{H}_{2} \mathrm{SO}_{4}
$$

As part of AMD treatment, acidity neutralisation to $\mathrm{pH} 6$ 7 by alkaline reagent decreases the solubility of $\mathrm{Fe}$ and $\mathrm{Al}$, resulting in $\mathrm{Fe}$ and $\mathrm{Al}$ hydroxide precipitation and removal by sedimentation $[2,3]$. However, potentially ecotoxic metals (e.g., $\mathrm{Ni}, \mathrm{Zn}, \mathrm{Cu}, \mathrm{Pb}$, and $\mathrm{Cd}$ ) require a further increase in $\mathrm{pH}$ (to 8 or above) to precipitate as metal hydroxides [4-6]. Incomplete removal and resultant discharge of residual metals may affect downstream freshwater fish assemblages[7].
Previous studies have reported removal of $\mathrm{Ni}$ and $\mathrm{Zn}$ during AMD neutralisation, where these metals were removed to varying degrees via coprecipitation and sorption onto $\mathrm{Fe}$ and Al hydroxide precipitates [8-11]. Davies et al. [10] showed a negative correlation between dissolved $\mathrm{Zn}$ concentration and $\mathrm{Zn}$ incorporation into neutralised AMD floc. Batch experiments showed that, at $\mathrm{pH} 7$ and for ratios of $\mathrm{Zn}$ to sorbent of $1: 10$ to $1: 100$, between $70 \%$ and $90 \%$ of $\mathrm{Zn}$ was removed from AMD due to sorption to precipitated metal oxides $[12,13]$. A similar trend was shown for Ni removal (at a similar sorbent to metal concentration ratio) where $66 \%$ of $\mathrm{Ni}$ was adsorbed to hydrous iron oxide at $\mathrm{pH} 7$ [14].

The purpose of this paper is to investigate the importance of the surface area of floc formed during AMD neutralisation by three industrial alkaline reagents $\left(\mathrm{NaOH}, \mathrm{Ca}(\mathrm{OH})_{2}\right.$, and $\mathrm{CaCO}_{3}$ ) for $\mathrm{Ni}$ and $\mathrm{Zn}$ removal from AMD. As sorption is a solid-liquid interface process, we hypothesise that the 
sorption capacity of an AMD neutralised floc is proportional to its surface area.

\section{Experimental Methods}

2.1. Sample Collection. The AMD used in these trials was collected from a fully oxidised stream at the Stockton Coal Mine on the West Coast of the South Island of New Zealand, and stored in 20-L plastic drums. The sample was stored for two weeks to allow full settlement of TSS before the supernatant was carefully decanted off for lab trials. The AMD had a $\mathrm{pH}$ of 2.6 (determined in the lab) and an acidity of $815 \mathrm{mg} \mathrm{L}^{-1} \mathrm{CaCO}_{3}$ equivalent, as determined by titration to $\mathrm{pH} 7$.

2.2. AMD Neutralisation. The AMD neutralisation pathway was determined by titrating AMD with 5-mL increments of $0.1 \mathrm{M} \mathrm{NaOH}$ under constant mixing in a $1-\mathrm{L}$ beaker. The acidity (in $\mathrm{mg} \mathrm{L}^{-1} \mathrm{CaCO}_{3}$ equivalent) was determined based on the amount of $\mathrm{NaOH}$ required to neutralise the AMD to $\mathrm{pH} 7$.

The AMD was neutralised with $\mathrm{Ca}(\mathrm{OH})_{2}$ and $\mathrm{CaCO}_{3}$ in addition to $\mathrm{NaOH}$. A $1 \mathrm{M} \mathrm{NaOH}$ stock solution was made using laboratory-grade pelletised $\mathrm{NaOH} ; 1 \mathrm{M}$ stock slurries of $74 \mathrm{~g} \mathrm{~L}^{-1} \mathrm{Ca}(\mathrm{OH})_{2}$ (laboratory-grade, $>99.5 \%$ purity), and $100 \mathrm{~g} \mathrm{~L}^{-1} \mathrm{CaCO}_{3}$ (ultrafine limestone from Murchison Lime Works, >99\% purity) were used and homogenised using a magnetic stirrer throughout dosing. Stock solutions/slurries of alkaline reagents were used to allow volumetric dosing of AMD (up to $18 \mathrm{~mL}$ of slurry per litre of AMD), simulating the slurry dosing conditions in the field at the Stockton Coal Mine.

Jar stirrers were used for neutralisation of the AMD in 1-L beakers, with different mixing regimes for different alkaline reagents. The $\mathrm{NaOH}$ neutralised samples were dosed with $\mathrm{NaOH}$ followed by a 1-min rapid mixing phase $(100 \mathrm{rpm})$ and a 25 -min flocculation phase $(20 \mathrm{rpm})$, as neutralisation by $\mathrm{NaOH}$ was instantaneous. By contrast, the $\mathrm{Ca}(\mathrm{OH})_{2}$ and $\mathrm{CaCO}_{3}$ neutralised samples were dosed with slurry followed by a $60-\mathrm{min}$ rapid mixing phase $(100 \mathrm{rpm})$. In order to determine residual metal concentrations in the circumneutral $\mathrm{pH}$ range, a range of alkaline reagent doses were used to neutralise AMD to between $\mathrm{pH} 6$ and 7.5 for $\mathrm{NaOH}$ and $\mathrm{Ca}(\mathrm{OH})_{2}$, and between $\mathrm{pH} 6$ and 8 for $\mathrm{CaCO}_{3}$. Neutralisation by $\mathrm{Ca}(\mathrm{OH})_{2}$ was essentially instantaneous, while a continued increase in $\mathrm{pH}$ (to a maximum $\mathrm{pH}$ of 8 ) was recorded for neutralisation using $\mathrm{CaCO}_{3}$ up to seven days after dosing. The slow dissolution kinetics of $\mathrm{CaCO}_{3}$ was also documented in earlier studies $[15,16]$. In total, $21 \mathrm{Ca}(\mathrm{OH})_{2}, 15 \mathrm{NaOH}$, and 7 $\mathrm{CaCO}_{3}$ neutralised samples were prepared.

At the end of the flocculation/mixing period, the beakers of neutralised AMD were allowed to settle for 2 hours. After settling, a $10 \mathrm{~mL}$ supernatant sample was drawn off using a syringe from $10 \mathrm{~mm}$ below the water surface, to avoid sampling of any floc remaining in the water column. The sample was filtered $(0.45 \mu \mathrm{m})$ into a plastic test tube and acidified $(\mathrm{pH}<2)$ using $68 \%$ nitric acid before storage in a fridge at $4^{\circ} \mathrm{C}$. The major cations ( $\mathrm{Na}, \mathrm{Mg}, \mathrm{Al}, \mathrm{Mn}$, and $\left.\mathrm{Fe}\right)$
TABLE 1: Concentration $\left(\mathrm{mg} \mathrm{L}^{-1}\right)$ of major cations, trace elements, and anions in the acid mine drainage.

\begin{tabular}{lccccccccc}
\hline & \multicolumn{4}{c}{ Major cations } & \multicolumn{4}{c}{ Trace elements } & Anion \\
\hline $\mathrm{Na}$ & $\mathrm{Mg}$ & $\mathrm{Al}$ & $\mathrm{Mn}$ & $\mathrm{Fe}$ & $\mathrm{Ca}$ & $\mathrm{Ni}$ & $\mathrm{Cu}$ & $\mathrm{Zn}$ & $\mathrm{SO}_{4}{ }^{2-}$ \\
13.1 & 20.7 & 86.0 & 2.6 & 45.9 & 37.7 & 0.75 & 0.91 & 4.42 & 1100 \\
\hline
\end{tabular}

and trace elements $(\mathrm{Ni}, \mathrm{Cu}$, and $\mathrm{Zn})$ were determined using an Agilent 7500cx (California, USA) Inductively Coupled Plasma Mass Spectrometry (ICP-MS) instrument, under standard hot plasma. For quality control, every tenth sample was duplicated and every twentieth was spiked, after which three blanks were run before further analysis. The instrument detection limits were determined using the three-sigma method (multiplying the standard deviation of the metal concentrations of blank samples by three). The experimental detection limits were 100 times the instrument detection limits (as samples were diluted 100x before analysis), corresponding to $0.007 \mathrm{mg} \mathrm{L}^{-1}$ and $0.014 \mathrm{mg} \mathrm{L}^{-1}$ for $\mathrm{Ni}$ and $\mathrm{Zn}$, respectively. The Ca concentration of the AMD was determined using the EDTA titrimetric method described in the APHA standard methods textbook [17]. The sulphate concentration was determined by $\mathrm{HACH}$ spectrophotometer using Method 8051.

2.3. AMD Precipitate Analysis. After the $10 \mathrm{~mL}$ supernatant sample was collected, the remaining supernatant was carefully decanted, leaving only the sludge layer. The sludge from beakers of $\mathrm{NaOH}, \mathrm{Ca}(\mathrm{OH})_{2}$, and $\mathrm{CaCO}_{3}$ neutralised $\mathrm{AMD}$ to $\mathrm{pH} 6.5$ was then poured into separate plastic containers and allowed to dewater by gravity overnight before freezedrying. The three floc samples $\left(\mathrm{NaOH}, \mathrm{Ca}(\mathrm{OH})_{2}\right.$, and $\mathrm{CaCO}_{3}$ neutralised AMD) were analysed for BET surface area at the University of Windsor using a Quantachrome Instruments Nova 1200e Surface Area and Pore Size Analyzer (Florida, USA). Each sample was degassed under vacuum at room temperature for 24 hours prior to nitrogen gas adsorption analysis at liquid nitrogen temperatures.

The precipitate chemical composition was analysed by borate fusion X-ray fluorescence spectrometry (XRF) at CRL Energy Ltd. Solid samples for XRF analysis were dried at $110^{\circ} \mathrm{C}$ and finely ground in a ring mill. Boric acid backed discs (40 mm diameter by 1-10 mm thick) of ground material were prepared under high pressure and analysed under vacuum. The multi-element XRF scanning procedure (Semiquant) was calibrated using Siemens standard samples containing known concentrations (ISO 17025).

\section{Results and Discussion}

3.1. AMD Composition and Fe/Al Precipitation. The concentrations of major cations, trace elements, and anions in the AMD are shown on Table 1, which are typical and comparable with previous studies $[18,19]$.

Figure 1 shows the neutralisation pathway of AMD determined by $\mathrm{NaOH}$ titration. Two buffer zones were clearly visible at $\mathrm{pH} \sim 3.3(\mathrm{Fe})$ and $\mathrm{pH} \sim 4.5(\mathrm{Al})$, which corresponded 


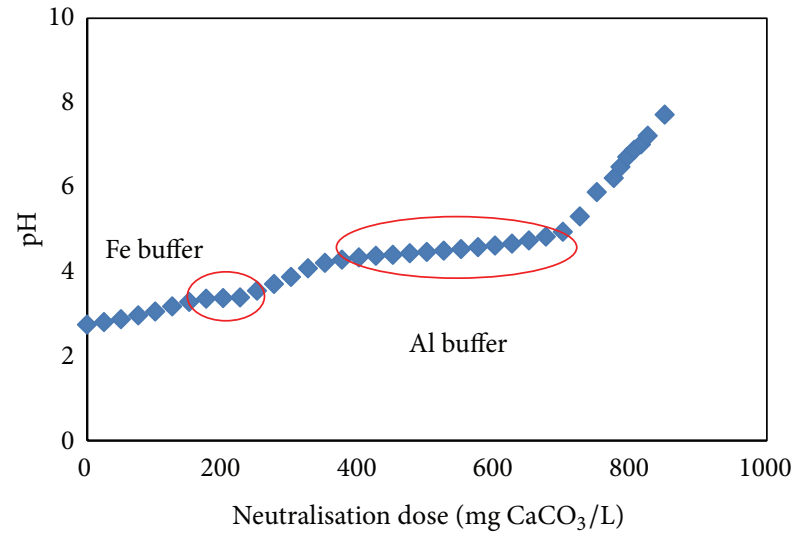

FIGURE 1: Neutralisation pathway of AMD (determined by $0.1 \mathrm{M}$ $\mathrm{NaOH}$ titration).

TABLE 2: Results of major oxide by XRF for $\mathrm{Ca}(\mathrm{OH})_{2}$ and $\mathrm{CaCO}_{3}$ neutralised AMD precipitates.

\begin{tabular}{lcc}
\hline wt.\% & \multicolumn{3}{c}{ Alkaline reagent } \\
& $\mathrm{Ca}(\mathrm{OH})_{2}$ & $\mathrm{CaCO}_{3}$ \\
\hline $\mathrm{SiO}_{2}$ & 15.4 & 3.5 \\
$\mathrm{Al}_{2} \mathrm{O}_{3}$ & 30.4 & 15.2 \\
$\mathrm{Fe}_{2} \mathrm{O}_{3}$ & 21.1 & 9.4 \\
$\mathrm{CaO}$ & 1.5 & 33.7 \\
$\mathrm{SO}_{3}$ & 4.9 & 3.6 \\
$\mathrm{Na}_{2} \mathrm{O}$ & 0.3 & 0.1 \\
$\mathrm{LOI}$ & 29.1 & 34.0 \\
\hline
\end{tabular}

to the hydrolysis of $\mathrm{Fe}$ and $\mathrm{Al}$ that resulted in the formation of metal hydroxide precipitates and the release of $\mathrm{H}^{+}$(see (2)). These precipitates provided the solid phase for sorption of $\mathrm{Ni}$ and $\mathrm{Zn}$. All AMD in this trial were neutralised to the $\mathrm{pH}$ 6-8 range, resulting in removal of $98.9 \%$, and $99.9 \%$ of $\mathrm{Fe}$ and $\mathrm{Al}$, respectively:

$$
\begin{aligned}
& \mathrm{Fe}^{3^{+}}+3 \mathrm{H}_{2} \mathrm{O} \Longrightarrow \mathrm{Fe}(\mathrm{OH})_{3(\mathrm{~s})}+3 \mathrm{H}^{+} \\
& \mathrm{Al}^{3+}+3 \mathrm{H}_{2} \mathrm{O} \Longrightarrow \mathrm{Al}(\mathrm{OH})_{3(\mathrm{~s})}+3 \mathrm{H}^{+}
\end{aligned}
$$

3.2. AMD Precipitate Properties. The flocs formed by $\mathrm{NaOH}$ and $\mathrm{Ca}(\mathrm{OH})_{2}$ neutralisation of AMD had a surface area an order of magnitude (173.7 and $168.2 \mathrm{~m}^{2} \mathrm{~g}^{-1}$, resp.) higher than the $\mathrm{CaCO}_{3}$ neutralised floc $\left(16.7 \mathrm{~m}^{2} \mathrm{~g}^{-1}\right)$. The surface areas of $\mathrm{NaOH}$ and $\mathrm{Ca}(\mathrm{OH})_{2}$ neutralised AMD floc are similar to amorphous $\mathrm{Fe}$ and $\mathrm{Al}$ hydroxide precipitates formed by other treatment methods (85.4 to $\left.135.4 \mathrm{~m}^{2} \mathrm{~g}^{-1},[11,20]\right)$. The difference in floc structures between the alkaline reagents was visible by inspection (Figure 2). Flocs formed by $\mathrm{NaOH}$ and $\mathrm{Ca}(\mathrm{OH})_{2}$ neutralisation were fluffy and amorphous in appearance, visually suggesting a low density and a high surface area, contrary to the floc formed by $\mathrm{CaCO}_{3}$ neutralisation which had a granular appearance as it contained alot of unreacted $\mathrm{CaCO}_{3}$ particulates (Table 2).

The XRF analysis of the sludge samples (Table 2) showed that 21 wt. $\%$ and $30 \mathrm{wt} . \%$ of the $\mathrm{Ca}(\mathrm{OH})_{2}$ neutralised AMD

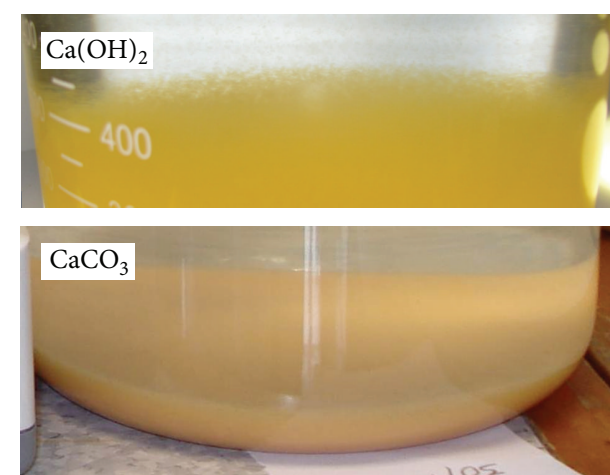

Figure 2: Fluffy $\mathrm{Ca}(\mathrm{OH})_{2}$ floc compared to dense $\mathrm{CaCO}_{3}$ floc.

sludge was $\mathrm{Fe}$ and $\mathrm{Al}$ oxides, respectively, which were recognised as the active sites for metal sorption $[8,10,11]$. Only 9 wt. $\%$ and 15 wt. $\%$ of the $\mathrm{CaCO}_{3}$ neutralised AMD sludge were $\mathrm{Fe}$ and $\mathrm{Al}$ oxides, respectively, due to significant unreacted $\mathrm{CaCO}_{3}$ bulking out the sludge. Relatively high losson-ignition (LOI) values were reported, probably reflecting the amount of $\mathrm{CaCO}_{3}$ and physisorbed water. The $\mathrm{NaOH}$ neutralised sludge was assumed to be compositionally similar to the $\mathrm{Ca}(\mathrm{OH})_{2}$ sludge as the neutralisation efficiencies for both $\mathrm{NaOH}$ and $\mathrm{Ca}(\mathrm{OH})_{2}$ were close to $100 \%$.

\subsection{Residual Metal Concentration}

3.3.1. Ni Sorption. Figure 3 shows that $\mathrm{Ni}$ concentration was lower at a given $\mathrm{pH}$ for $\mathrm{NaOH}$ and $\mathrm{Ca}(\mathrm{OH})_{2}$ neutralised AMD compared to $\mathrm{CaCO}_{3}$ neutralised AMD. For example, at $\mathrm{pH}$ 6.5, Ni concentration was 0.32 and $0.41 \mathrm{mg} \mathrm{L}^{-1}$ for $\mathrm{NaOH}$ and $\mathrm{Ca}(\mathrm{OH})_{2}$ neutralised $\mathrm{AMD}$, respectively. This was up to $60 \%$ lower than the $\mathrm{CaCO}_{3}$ neutralised $\mathrm{Ni}$ concentration of $0.8 \mathrm{mg} \mathrm{L}^{-1}$ at the same $\mathrm{pH}$. A relatively linear trend between $\mathrm{pH}$ and $\mathrm{Ni}$ concentration was shown for all three alkaline reagents in Figure 3. This was probably because the potential of $\mathrm{Ni}$ sorption and coprecipitation increased proportionally with increasing surface deprotonation of the AMD sludge at $\mathrm{pH}$ above the point of zero charge $[6,21,22]$. Over the range of pH 6 to 8, Ni concentration after $\mathrm{CaCO}_{3}$ neutralisation was approximately $0.4 \mathrm{mg} \mathrm{L}^{-1}$ higher than that of the other two alkaline reagents. Since the surface area of $\mathrm{CaCO}_{3}$ neutralised floc was an order of magnitude less per unit mass, this suggests that the greater surface area of flocs produced by $\mathrm{NaOH}$ and $\mathrm{Ca}(\mathrm{OH})_{2}$ neutralised $\mathrm{AMD}$ increased the removal of Ni.

3.3.2. Zn Sorption. Figure 4 shows that the sorption of $\mathrm{Zn}$ (initial concentration of $4.42 \mathrm{mg} \mathrm{L}^{-1}$ ) was even more dependent than $\mathrm{Ni}$ on neutralisation reagent. For example, at $\mathrm{pH}$ 6.5, $\mathrm{Zn}$ concentration was 0.33 and $1.02 \mathrm{mg} \mathrm{L}^{-1}$ in the $\mathrm{NaOH}$ and $\mathrm{Ca}(\mathrm{OH})_{2}$ neutralised AMD. This was $85 \%$ and $54 \%$ lower (for $\mathrm{NaOH}$ and $\mathrm{Ca}(\mathrm{OH})_{2}$, resp.) than $\mathrm{Zn}$ concentration of $2.20 \mathrm{mg} \mathrm{L}^{-1}$ in the $\mathrm{CaCO}_{3}$ neutralised AMD at the same $\mathrm{pH}$. The clustering of data points at $\mathrm{pH} 6$ suggests that about half of $\mathrm{Zn}$ removal occurred irrespective of the 


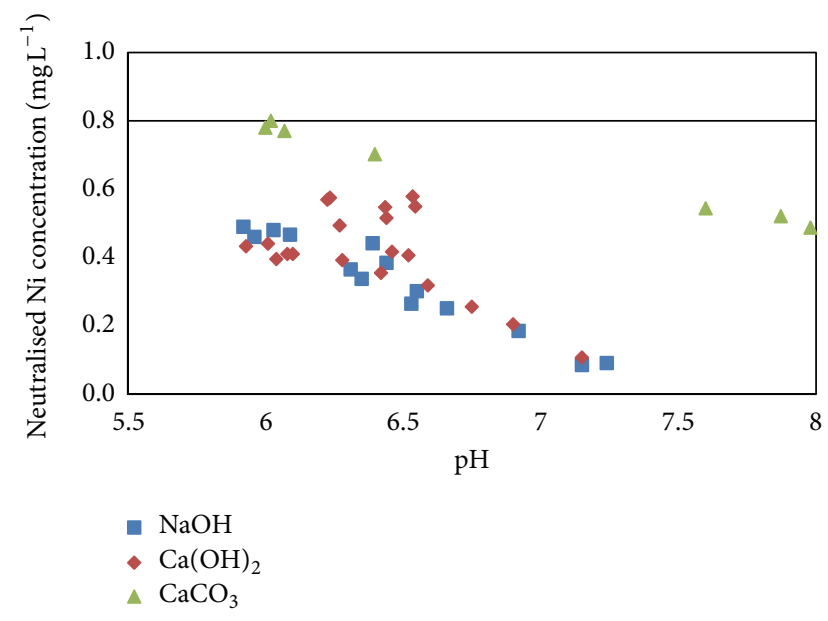

FIGURE 3: Acid mine drainage Ni concentration (initial $=0.8 \mathrm{mg} \mathrm{L}^{-1}$ ) and concentration after neutralisation by $\mathrm{NaOH}, \mathrm{Ca}(\mathrm{OH})_{2}$, and $\mathrm{CaCO}_{3}$.

neutralisation reagent used. Between $\mathrm{pH} 6$ and 6.5, the data diverged with a residual $\mathrm{Zn}$ concentration hierarchy of $\mathrm{NaOH}$ neutralised $<\mathrm{Ca}(\mathrm{OH})_{2}$ neutralised $<\mathrm{CaCO}_{3}$ neutralised. This may correspond to the saturation of the limited sorption sites on $\mathrm{CaCO}_{3}$ neutralised precipitates, while the greater surface area of $\mathrm{NaOH}$ and $\mathrm{Ca}(\mathrm{OH})_{2}$ precipitates allowed $\mathrm{Zn}$ sorption and coprecipitation to continue $[8,21]$.

3.3.3. Calcium Competition. The difference in $\mathrm{Zn}$ removal from $\mathrm{NaOH}$ and $\mathrm{Ca}(\mathrm{OH})_{2}$ neutralised $\mathrm{AMD}$ at a given $\mathrm{pH}$ may also result from the effect of background cations. Neutralisation of $\mathrm{AMD}$ using $\mathrm{NaOH}$ and $\mathrm{Ca}(\mathrm{OH})_{2}$ was found to result in the release of significant quantities of $\mathrm{Na}$ and $\mathrm{Ca}$ $\left(\sim 400 \mathrm{mg} \mathrm{L}^{-1}\right)$, respectively. Dissolved Ca complexation with hydroxyl groups was potentially significant given the elevated Ca concentrations after neutralisation [23]. Thus, competition for binding sites on AMD precipitates from Ca may be responsible for the reduction in $\mathrm{Zn}$ removal when comparing $\mathrm{NaOH}$ and $\mathrm{Ca}(\mathrm{OH})_{2}$ neutralisation systems (Figure 4). In the case of $\mathrm{CaCO}_{3}$ neutralisation, the combination of low precipitate surface area and $\mathrm{Ca}$ competition for sorption sites led to significantly lower sorption of $\mathrm{Ni}$ and $\mathrm{Zn}$.

There was a minor difference in $\mathrm{NaOH}$ and $\mathrm{Ca}(\mathrm{OH})_{2}$ neutralised AMD Ni concentrations, which suggests $\mathrm{Ca}$ competition does not affect Ni removal. This may be due to the relatively low $\mathrm{Ni}$ concentration in AMD, and the relatively low tendency for $\mathrm{Ni}$ to adsorb onto the precipitates rendering Ca competition for binding sites negligible.

\section{Conclusions}

The removal of $\mathrm{Ni}$ and $\mathrm{Zn}$ by sorption onto AMD precipitates is influenced by the surface area of floc formed during neutralisation. Neutralisation of AMD by $\mathrm{NaOH}$ and $\mathrm{Ca}(\mathrm{OH})_{2}$ produces large fluffy floc, with surface areas, an order of magnitude greater than floc formed by $\mathrm{CaCO}_{3}$ neutralisation. As a result, significantly more $\mathrm{Ni}$ and $\mathrm{Zn}$ were sorbed and

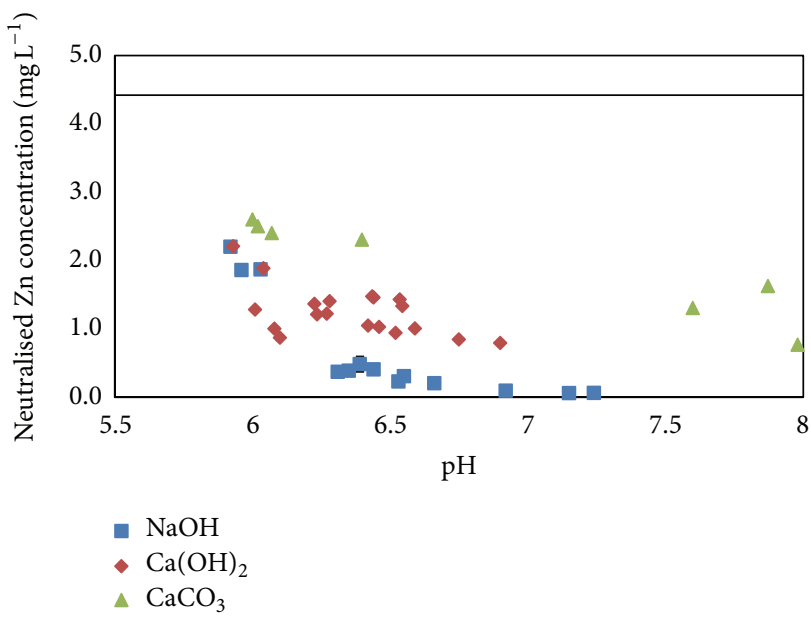

FIgURE 4: Acid mine drainage $\mathrm{Zn}$ concentration (initial = $4.42 \mathrm{mg} \mathrm{L}^{-1}$ ) and concentration after neutralisation by $\mathrm{NaOH}$, $\mathrm{Ca}(\mathrm{OH})_{2}$, and $\mathrm{CaCO}_{3}$.

coprecipitated on the $\mathrm{NaOH}$ and $\mathrm{Ca}(\mathrm{OH})_{2}$ floc. Moreover, competition for sorption sites from the Ca released during $\mathrm{Ca}(\mathrm{OH})_{2}$ dissociation appears to reduce the removal of $\mathrm{Zn}$ when compared to $\mathrm{NaOH}$ neutralised AMD. These results account for the lower $\mathrm{Ni}$ and $\mathrm{Zn}$ concentrations in water discharged from treatment systems using $\mathrm{NaOH}$ or $\mathrm{Ca}(\mathrm{OH})_{2}$ as opposed to $\mathrm{CaCO}_{3}$, which is an important consideration when selecting alkaline reagents for AMD treatment.

\section{Acknowledgment}

The authors thank the Foundation for Research Science and Technology Fund for the financial support of this study under contract SENZ0901.

\section{References}

[1] J. Pope, N. Newman, D. Craw, D. Trumm, and R. Rait, "Factors that influence coal mine drainage chemistry West Coast, South Island, New Zealand," New Zealand Journal of Geology and Geophysics, vol. 53, no. 2-3, pp. 115-128, 2010.

[2] D. B. Johnson and K. B. Hallberg, "Acid mine drainage remediation options: a review," Science of the Total Environment, vol. 338, no. 1-2, pp. 3-14, 2005.

[3] D. Trumm, "Selection of active and passive treatment systems for AMD-flow charts for New Zealand conditions," New Zealand Journal of Geology and Geophysics, vol. 53, no. 2-3, pp. 195-210, 2010.

[4] F. Morel, Principles of Aquatic Chemistry, John Wiley \& Sons, 1983.

[5] M. Kelly, Mining and the Freshwater Environment, Elsevier Applied Science, Durham, UK, 1988.

[6] P. L. Younger, S. A. Banwart, and R. S. Hedin, Mine Water: Hydrology, Pollution, Remediation, Kluwer Academic Publishers, Dordrecht, The Netherlands, 2002.

[7] H. S. Greig, D. K. Niyogi, K. L. Hogsden, P. G. Jellyman, and J. S. Harding, "Heavy metals: confounding factors in the response of New Zealand freshwater fish assemblages to natural and 
anthropogenic acidity," Science of the Total Environment, vol. 408, no. 16, pp. 3240-3250, 2010.

[8] G. Lee, J. M. Bigham, and G. Faure, "Removal of trace metals by coprecipitation with $\mathrm{Fe}, \mathrm{Al}$ and $\mathrm{Mn}$ from natural waters contaminated with acid mine drainage in the Ducktown Mining District, Tennessee," Applied Geochemistry, vol. 17, no. 5, pp. 569-581, 2002.

[9] B. G. Lottermoser, Mine Wastes: Characterization, Treatment and Environmental Impacts, Springer, Cairns, Australia, 2003.

[10] H. Davies, P. Weber, P. Lindsay, D. Craw, B. Peake, and J. Pope, "Geochemical changes during neutralisation of acid mine drainage in a dynamic mountain stream, New Zealand," Applied Geochemistry, vol. 26, no. 12, pp. 2121-2133, 2011.

[11] M. Cui, M. Jang, S.-H. Cho, J. Khim, and F. S. Cannon, "A continuous pilot-scale system using coal-mine drainage sludge to treat acid mine drainage contaminated with high concentrations of $\mathrm{Pb}, \mathrm{Zn}$, and other heavy metals," Journal of Hazardous Materials, vol. 215-216, pp. 122-128, 2012.

[12] M. F. Schultz, M. M. Benjamin, and J. F. Ferguson, "Adsorption and desorption of metals on ferrihydrite: reversibility of the reaction and sorption properties of the regenerated solid," Environmental Science and Technology, vol. 21, no. 9, pp. 863869, 1987.

[13] J. G. Webster, P. J. Swedlund, and K. S. Webster, "Trace metal adsorption onto an acid mine drainage iron(III) oxy hydroxy sulfate," Environmental Science and Technology, vol. 32, no. 10, pp. 1361-1368, 1998.

[14] Y. Xu, L. Axe, T. Boonfueng, T. A. Tyson, P. Trivedi, and K. Pandya, "Ni(II) complexation to amorphous hydrous ferric oxide: an X-ray absorption spectroscopy study," Journal of Colloid and Interface Science, vol. 314, no. 1, pp. 10-17, 2007.

[15] E. L. Sjöberg and D. T. Rickard, "Calcite dissolution kinetics: surface speciation and the origin of the variable $\mathrm{pH}$ dependence," Chemical Geology, vol. 42, no. 1-4, pp. 119-136, 1984.

[16] M. Alkattan, E. H. Oelkers, J.-L. Dandurand, and J. Schott, "An experimental study of calcite and limestone dissolution rates as a function of $\mathrm{pH}$ from -1 to 3 and temperature from 25 to $80^{\circ} \mathrm{C}$," Chemical Geology, vol. 151, no. 1-4, pp. 199-214, 1998.

[17] American Public Health Association (APHA), Standard Methods for the Examination of Water \& Wastewater, Washington, DC, USA, 2005.

[18] C. A. McCauley, A. D. O'Sullivan, P. A. Weber, and D. Trumm, "Variability of stockton coal mine drainage chemistry and its treatment potential with biogeochemical reactors," New Zealand Journal of Geology and Geophysics, vol. 53, no. 2-3, pp. 211-226, 2010.

[19] W. E. Olds, D. C. W. Tsang, and P. Weber, "Acid mine drainage treatment assisted by lignite-derived humic substances," Water, Air, \& Soil Pollution, vol. 224, pp. 1521-1533, 2013.

[20] P. R. Adler and P. L. Sibrell, "Sequestration of phosphorus by acid mine drainage floc," Journal of Environmental Quality, vol. 32, no. 3, pp. 1122-1129, 2003.

[21] R. J. Crawford, I. H. Harding, and D. E. Mainwaring, "Adsorption and coprecipitation of single heavy metal ions onto the hydrated oxides of iron and chromium," Langmuir, vol. 9, no. 11, pp. 3050-3056, 1993.

[22] J. G. Webster, "Chemical processes affecting trace metal transport in the Waihou River and estuary, New Zealand," New Zealand Journal of Marine and Freshwater Research, vol. 29, no. 4, pp. 539-553, 1995.

[23] V. L. Snoeyink and D. Jenkins, Water Chemistry, John Wiley \& Sons, 1980. 

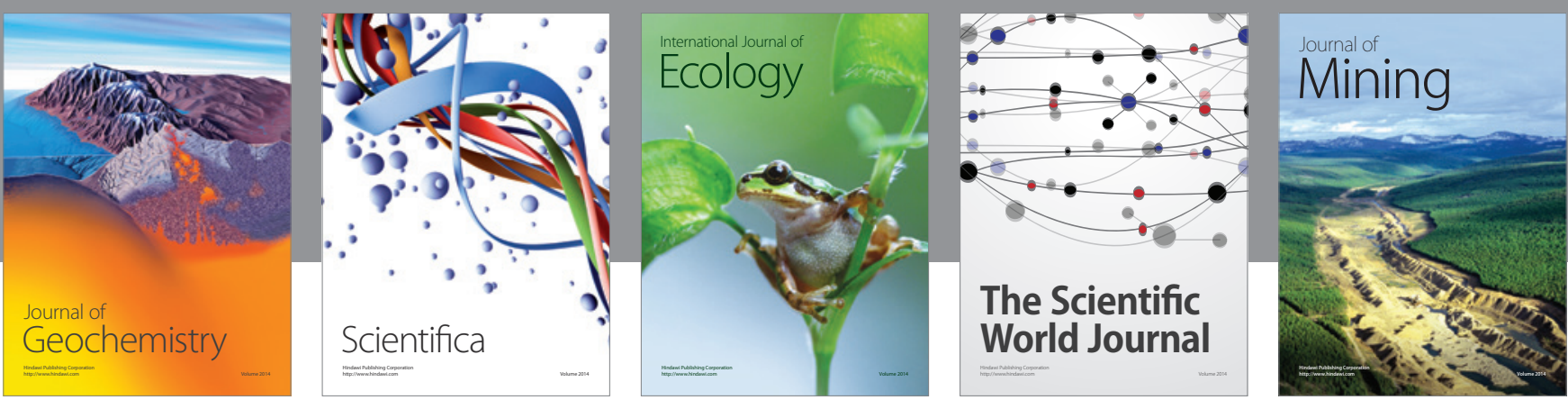

The Scientific World Journal
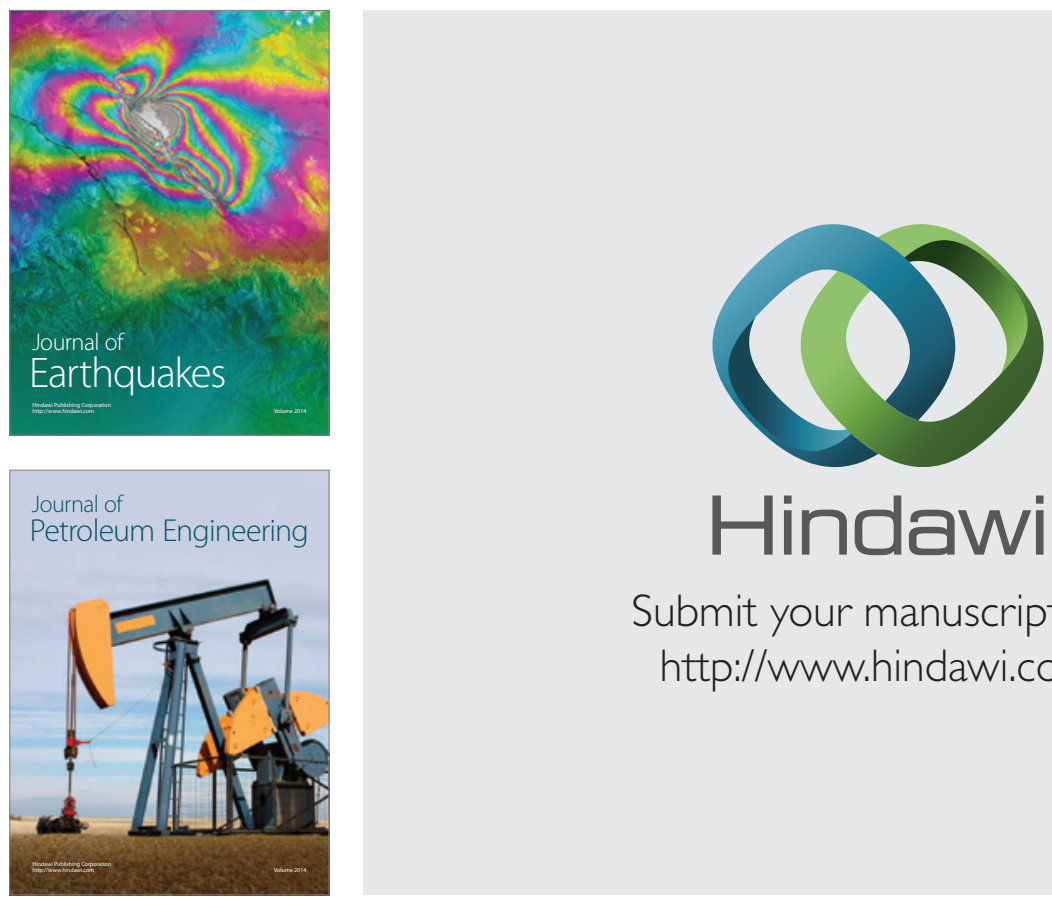

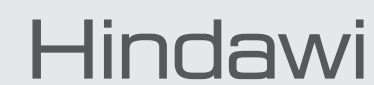

Submit your manuscripts at

http://www.hindawi.com
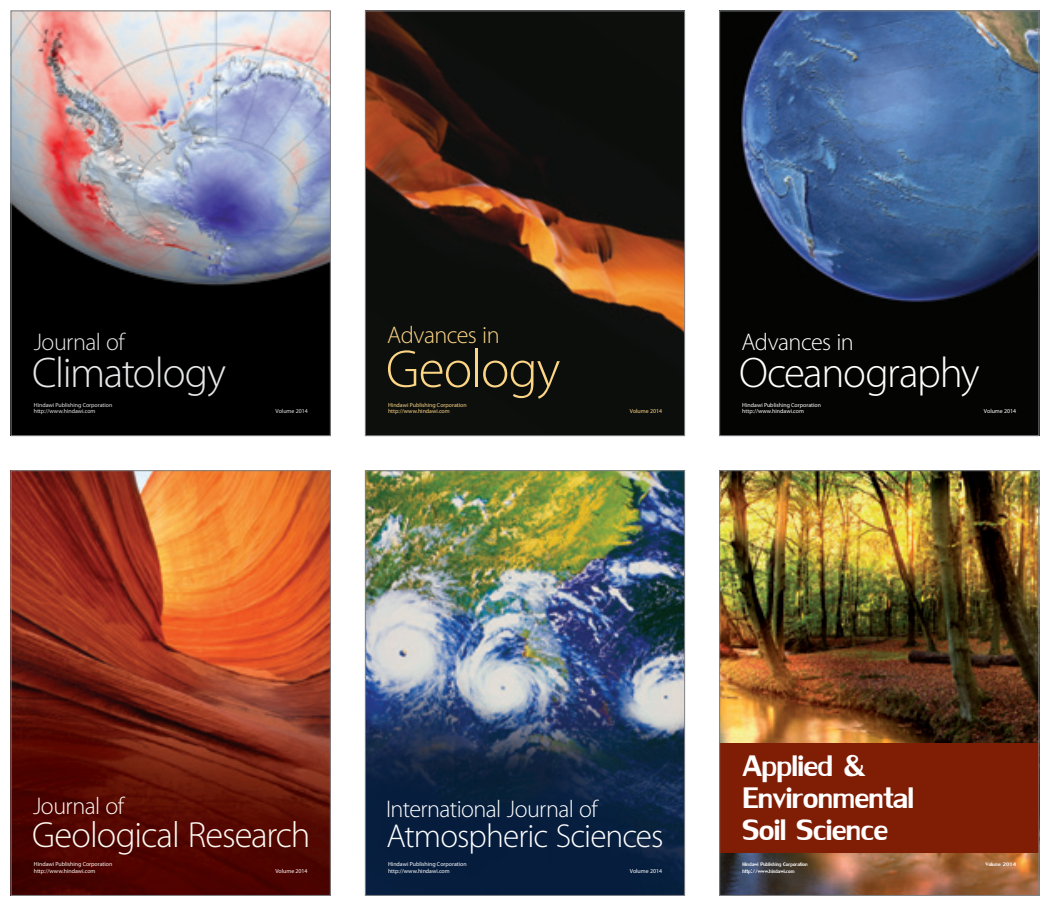
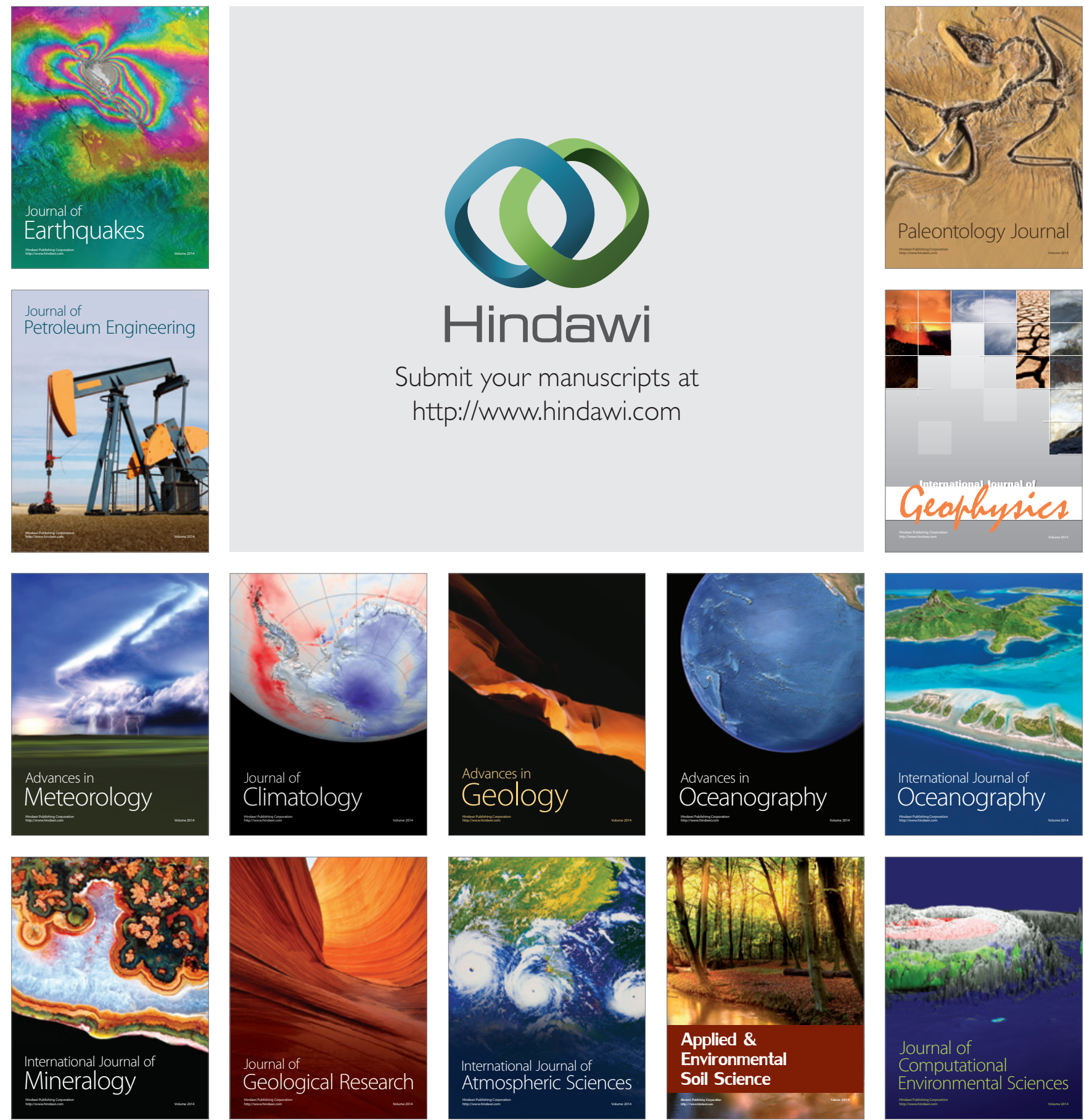